\title{
Na de LTS: doorleren of werken?
}

\author{
Citation for published version (APA):
}

Heijke, J. A. M., \& Wieling, M. (1991). Na de LTS: doorleren of werken? Researchcentrum voor Onderwijs en Arbeidsmarkt, Faculteit der Economische Wetenschappen. ROA Research Memoranda No. 4 https://doi.org/10.26481/umaror.1991004

Document status and date:

Published: 01/01/1991

DOI:

10.26481/umaror.1991004

Document Version:

Publisher's PDF, also known as Version of record

\section{Please check the document version of this publication:}

- A submitted manuscript is the version of the article upon submission and before peer-review. There can be important differences between the submitted version and the official published version of record.

People interested in the research are advised to contact the author for the final version of the publication, or visit the DOI to the publisher's website.

- The final author version and the galley proof are versions of the publication after peer review.

- The final published version features the final layout of the paper including the volume, issue and page numbers.

Link to publication

\footnotetext{
General rights rights.

- You may freely distribute the URL identifying the publication in the public portal. please follow below link for the End User Agreement:

www.umlib.nl/taverne-license

Take down policy

If you believe that this document breaches copyright please contact us at:

repository@maastrichtuniversity.nl

providing details and we will investigate your claim.
}

Copyright and moral rights for the publications made accessible in the public portal are retained by the authors and/or other copyright owners and it is a condition of accessing publications that users recognise and abide by the legal requirements associated with these

- Users may download and print one copy of any publication from the public portal for the purpose of private study or research.

- You may not further distribute the material or use it for any profit-making activity or commercial gain

If the publication is distributed under the terms of Article $25 \mathrm{fa}$ of the Dutch Copyright Act, indicated by the "Taverne" license above, 


\title{
NA DE LTS: DOORLEREN OF WERKEN?
}

\author{
ROA-RM-1991/4
}

J.A.M. Heijke en M.H. Wieling

Faculteit der Economische Wetenschappen

Rijksuniversiteit Limburg

Maastricht, april 1991 
Heijke, J.A.M.

Na de Its: doorleren of werken? / J.A.M. Heijke en M.H. Wieling. - Maastricht: Researchcentrum voor Onderwijs en Arbeidsmarkt, Faculteit der Economische Wetenschappen, Rijksuniversiteit Limburg. - Research memorandum / Researchcentrum voor Onderwijs en Arbeidsmarkt; 1991/4). Met lit. opg.

ISBN 90-5321-057-1 in spiraalband

Trefw.: schoolverlaters; lager technisch onderwijs. 
INHOUDSOPGAVE

Bladzijde

$\begin{array}{lr}\text { 1. INLEIDING } & 1\end{array}$

2. THEORIEËN 3

3. DATA EN VARIABELEN $\quad 5$

$\begin{array}{lr}\text { 4. MODEL } & 8\end{array}$

5. SCHATTINGSRESULTATEN 11

$\begin{array}{lr}\text { 6. CONCLUSIES } & 16\end{array}$

$\begin{array}{lr}\text { LITERATUUR } & 17\end{array}$

$\begin{array}{lr}\text { BIJLAGE 1: HET BINOMIALE LOGIT-MODEL } & 18\end{array}$

BIJLAGE 2: HET MULTINOMIALE LOGIT-MODEL 20 


\section{INLEIDING}

Op de arbeidsmarkt is een toenemend tekort ontstaan aan schoolverlaters die lager technisch onderwijs hebben genoten. Het bedrijfsleven heeft vooral behoefte aan leerlingen die de lagere technische school (LTS) op de hogere C- of D-niveaus hebben afgesloten. De oorzaken van het tekort kunnen aan zowel de vraagzijde als de aanbodzijde van de arbeidsmarkt worden gezocht. De toenemende behoefte van het bedrijfsleven aan LTS-ers heeft ongetwijfeld te maken met het, inmiddels al weer enkele jaren voortdurende, herstel van de economische recessie uit de jaren tachtig. In dit verband moet in het bijzonder de industriële werkgelegenheid worden genoemd, die na jaren van teruggang aan een nieuwe opmars is begonnen. Aan de aanbodzijde van de arbeidsmarkt zijn vooral de ontgroening van de bevolking en de nog steeds toenemende belangstelling voor het volgen van Algemeen Voortgezet Onderwijs na de basisschool, verantwoordelijk voor de dalende uitstroom uit de LTS.

Uit voorgaande beschrijving kan gemakkelijk de indruk ontstaan dat de LTS tekortschiet als toeleverancier van arbeidskrachten aan de arbeidsmarkt. Dit zou de werkelijke functie van de LTS evenwel onrecht aan doen. Van de eindexamenleerlingen gaat globaal gesproken slechts vijf procent op zoek naar een volledige baan; ruim de helft wil voltijd onderwijs volgen en een derde deel wil dat alleen in deeltijd. De LTS is dus maar in beperkte mate toeleverancier aan de arbeidsmarkt. Een belangrijke functie is daarnaast gelegen in het bieden van een goede vooropleiding voor vervolgonderwijs.

De mate waarin de LTS toeleverancier is aan de arbeidsmarkt dan wel een vooropleidingsinstituut is, wordt vooral bepaald door de keuzen die de leerlingen maken met betrekking tot hun verdere loopbaan. De school heeft hierop waarschijnlijk slechts een beperkte invloed. In dit research memorandum zal worden getracht enig inzicht te krijgen in de factoren die bepalend zijn voor de keuze van LTS-eindexamenleerlingen voor wat zij direct na het examen willen gaan doen ${ }^{1}$. De te beschouwen keuzen zijn: voltijd onderwijs volgen, voltijd werken of deeltijd onderwijs volgen in combinatie met werken. In het geval dat de leerlingen voltijd verder willen gaan leren, wordt vervolgens onderzocht welke factoren de keuze van het type vervolgonderwijs bepalen.

De te onderzoeken factoren zullen worden ontleend aan een economische context. Het bovengenoemde keuzeprobleem wordt dus als een economisch vraagstuk beschouwd. Aanknopingspunten zullen daarom worden gezocht bij bestaande economische theorieën van het

1. Zie voor een uitvoerige verantwoording van het onderzoek Wieling (1990). 


$$
-2-
$$

keuzegedrag met betrekking tot onderwijs. De relevantie van de factoren die uit deze theorieën naar voren komen, zal worden nagegaan door het schatten van een econometrisch gespecificeerd keuzemodel. Deze schatting zal plaatsvinden op basis van gegevens van individuele eindexamenleerlingen van een lagere technische school. Door het kleine aantal waarnemingen en de beperking tot maar één school gaat het hier uitdrukkelijk om een verkennend onderzoek. Door de beperking tot éen school kan bijvoorbeeld niet de mogelijke invloed van schoolspecifieke of regiospecifieke factoren worden onderzocht. Binnen dit beperkte kader kan het onderzoek desalniettemin indicatieve resultaten opleveren.

De opzet van het research memorandum is als volgt. Eerst worden enkele economische theorieën besproken die relevant lijken voor een empirisch onderzoek naar de keuzen die LTSleerlingen maken ten aanzien van hetgeen zij willen gaan doen zodra zij hun eindexamen achter de rug hebben. Na het geven van een toelichting op de gebruikte data-set en de keuze van de verklarende variabelen, wordt het te schatten keuzemodel uiteengezet. Vervolgens worden de schattingsresultaten van de verschillende stappen uit het onderzochte keuzeproces weergegeven. Tenslotte worden enkele conclusies getrokken. 


\section{THEORIEËN}

Het in deze studie geformuleerde keuzeprobleem wordt als een economische vraagstuk beschouwd. Derhalve wordt aansluiting gezocht bij bestaande economische theorieën van het keuzegedrag met betrekking tot onderwijs. De achtereenvolgens te bespreken theorieën zijn de human capital theorie, de screening theorie en de labor queue theorie.

De human capital theorie (Schultz, 1961) gaat er van uit dat een individu zijn produktief vermogen kan vergroten door meer onderwijs te volgen. Volgens de neo-klassieke gedachtengang, waar de human capital theorie bij aansluit, is de beloning van arbeid gelijk aan de marginale arbeidsproduktiviteit. Daarom zal het individu als hij na het extra onderwijs genoten te hebben gaat werken een hogere beloning ontvangen dan in het geval hij direct was gaan werken. Tegenover deze baten in de vorm van extra inkomen staan ook kosten. Deze betreffen het gederfde inkomen tijdens de opleiding en de directe uitgaven aan lesgeld en studiemateriaal. Om baten en kosten, die elk op verschillende tijdsperioden betrekking hebben, met elkaar te kunnen vergelijken, moeten zij in contante waarden worden uitgedrukt. Hiervoor wordt een discontofactor gebruikt die de voorkeursverhouding aangeeft voor huidig inkomen boven toekomstig inkomen. Volgens de human capital theorie zal het individu onderwijs volgen zolang de contante baten groter zijn dan de contante kosten.

De tweede te bespreken theorie is de screening theorie (Stiglitz, 1975). Volgens deze theorie kan een individu zijn produktief vermogen niet vergroten door meer onderwijs te volgen. Het onderwijs onthult slechts de reeds aanwezige kwaliteiten van het individu. Het behaalde diploma vormt het selectiemiddel bij uitstek om vast te stellen hoe begaafd arbeidskrachten zijn. Hoe hoger het diploma des te begaafder en produktiever het individu zal zijn. Volgens de signaleringsvariant (Spence, 1973) van deze theorie spelen individuen zelf hierop in door een opleiding te kiezen die hun kwaliteiten voor werkgevers zichtbaar maakt. Omdat de screening door werkgevers plaatsvindt op basis van het behaalde diploma, vormt een afgebroken schoolloopbaan nutteloze jaren. Evenals bij de human capital theorie wordt de beloning bepaald door het behaalde opleidingsniveau. Bij de screening theorie is evenwel uitsluitend het bezit van het diploma van belang voor de hoogte van de beloning, terwijl bij de human capital theorie ook het tijdens de eventueel afgebroken schoolloopbaan genoten onderwijs, in de hoogte van de beloning tot uitdrukking komt.

De labor queue theorie (Thurow, 1979) gaat er evenals de screening theorie vanuit dat de voor de beroepsuitoefening vereiste kennis en vaardigheden niet in het onderwijs worden opgedaan. Slechts door middel van on-the-job training kunnen deze worden verkregen. Dit brengt kosten 
$-4-$

met zich mee. Naarmate het behaalde diploma hoger is zal de trainbaarheid groter zijn en de trainingskosten derhalve lager. Arbeidskrachten worden voor de beschikbare banen geworven volgens een arbeidsrij, waarbij de rangschikking wordt bepaald door het niveau van het behaalde diploma. In tegenstelling tot de human capital theorie en de screening theorie wordt volgens de labor queue theorie de beloning niet bepaald door de via het onderwijs verkregen of zichtbaar gemaakte kenmerken van het individu, maar door het niveau van de baan. De loonstructuur vormt daarbij een gegeven. Individuen zullen door hogere diploma's te halen, trachten in de arbeidsrij naar voren te schuiven, waardoor zij voor hogere en daardoor beter beloonde banen in aanmerking komen. 


\section{DATA EN VARIABELEN}

De relevantie van de besproken theorieën voor de loopbaankeuze van eindexamenleerlingen van de LTS zal worden onderzocht met behulp van gegevens die bij een lagere technische school zijn verzameld. De basis van deze gegevens wordt gevormd door een enquête die in maart 1988 onder alle eindexamenleerlingen van de desbetreffende school is gehouden (Stijnen en Wieling, 1988). Vervolgens zijn bij de school aanvullende gegevens van de betreffende leerlingen verzameld (Wieling, 1990). De enquête-gegevens hebben vooral betrekking op de vraag wat de leerlingen na het eindexamen willen gaan doen en de motieven die zij voor deze keuze aanvoeren. De aanvullende gegevens betreffen vooral de schoolprestaties en de sociale positie.

Figuur 1. Keuze van de eindexamenleerlingen in procenten.

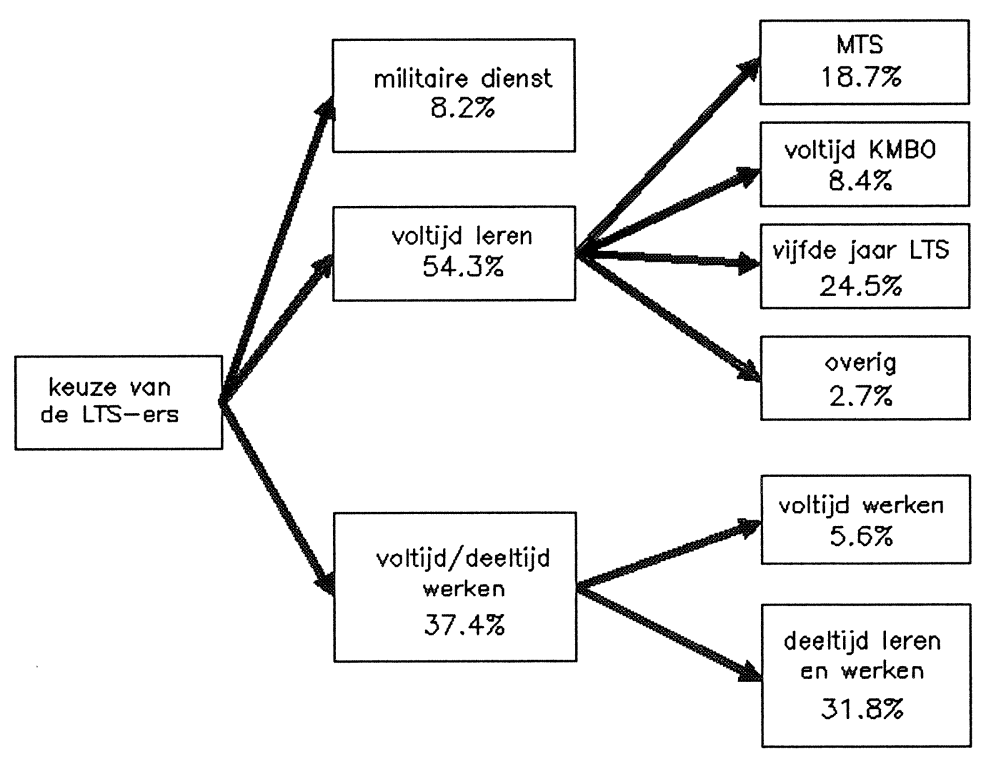

In figuur 1 wordt de loopbaankeuze van de eindexamenleerlingen weergegeven op het moment van enquêteren. Ruim de helft van de leerlingen kiest voor voltijd doorleren en bijna een derde wil dat in deeltijd doen in combinatie met werken. Het deel dat direct voltijd wil gaan werken is gering. De keuze van het type voltijd vervolgopleiding wordt eveneens weergegeven in figuur 1 . Bijna de helft van de leerlingen die voltijd willen doorleren wil terug naar de LTS voor een vijfde leerjaar om hun kwalificatie te verbeteren (profielverbeteraars). De leerlingen die hebben aangegeven na het eindexamen in militaire dienst te gaan, zullen niet in het onderzoek worden betrokken. De reden hiervoor is dat zij de keuze voor doorleren en/of werken pas na hun diensttijd maken. Verder konden van een groot aantal leerlingen geen aanvullende gegevens worden achterhaald. Voor de uit te voeren analyse resteren 145 van de 267 eindexamenleerlingen. 
Van de leerlingen is een groot aantal gegevens verzameld, deels via de enquête en deels aanvullend via de school. De gegevens die voor de uit te voeren analyse van belang lijken, zullen nu worden besproken.

De eerste groep gegevens betreft de keuzen die de leerlingen maken. Zij vormen de te verklaren variabelen in de onderhavige analyse. Het gaat hier om de keuze voor voltijd doorleren, deeltijd doorleren in combinatie met werken of een voltijd baan zoeken. Van de leerlingen die voltijd willen doorleren is vervolgens van belang voor welk type vervolgopleiding zij kiezen.

De volgende groep gegevens die voor de analyse van belang is, bestaat uit drie categorieën van verklarende variabelen. De eerste categorie binnen deze groep betreft de motieven die de leerlingen voor hun keuze aanvoeren. De besproken economische theorieën benadrukken alle drie het belang van de inkomensvooruitzichten voor het kiezen van een vervolgopleiding. Volgens de human capital theorie is dat vooral vanwege de mogelijkheid die de vervolgopleiding schept voor een hogere produktiviteit. Bij de screening theorie is dat vanwege de kans die het te behalen diploma biedt op een hogere baan. De labor queue theorie benadrukt dat deze kansverbetering loopt via het naar voren schuiven in de arbeidsrij. Het in de enquête onderscheiden motief "betere inkomensvooruitzichten" spoort het beste met deze theoretische noties.

Een volgend motief dat in de enquête werd onderscheiden is "het hebben van een bepaalde beroepswens". Dit motief valt moeilijk in verband te brengen met de drie genoemde theorieën. Deze theorieën richten zich immers eenzijdig op de beloning van het te verrichten werk als handelingsdoel, met veronachtzaming van de bevrediging die de inhoudelijke en professionele kanten van de beroepsuitoefening met zich kunnen meebrengen. Omdat het willen uitoefenen van een bepaald beroep een reële motivering lijkt voor de loopbaankeuze, wordt het toch meegenomen in de analyse. Alle overige motieven die in de enquête zijn onderscheiden blijven verder buiten beschouwing, omdat zij sterk samenhangen met de genoemde twee motieven of omdat zij niet aan alle respondenten zijn voorgelegd.

De tweede categorie verklarende variabelen betreft de kans op succesvolle afsluiting van de vervolgopleiding. Deze factor speelt een rol bij de screening theorie. Als men het diploma niet haalt is alle investering immers nutteloos geweest. Bij de human capital theorie ligt dit anders, omdat volgens deze theorie door elke (opgedane) onderwijservaring iemands produktiviteit toeneemt.

De ingeschatte kans op succes zal vooral worden afgeleid uit de eigen studieprestaties. 
Gegevens van de leerlingen hierover zijn aanvullend bij de school verzameld. De volgende variabelen zijn op basis van deze gegevens samengesteld:

- de leerling heeft studieniveau $A$ of $A / B$;

- de leerling heeft studieniveau B;

- de leerling heeft studieniveau $B / C, C, C / D$ of $D$;

- de leerling is profielverbeteraar;

- de leerling is blijven zitten ("doubleur");

- het 10 van de leerling;

- het gemiddelde cijfer voor talen;

- het gemiddelde cijfer voor wis- en natuurkunde;

- het gemiddelde cijfer voor de praktijkvakken;

- het gemiddelde cijfer voor alle vakken.

De derde categorie verklarende variabelen heeft betrekking op het sociale milieu en de gezinssituatie. Deze kunnen immers indicatief zijn voor het ontvangen van gebrekkige of selectieve informatie over de latere loopbaanmogelijkheden. Ze kunnen echter ook wijzen op mogelijke budgettaire beperkingen voor voltijd doorleren. Het gebrek aan informatie over de loopbaanmogelijkheden speelt geen rol in de besproken economische theorieën. Budgettaire beperkingen zijn evenwel gemakkelijk in verband te brengen met de human capital theorie. In deze theorie worden de latere baten van de vervolgopleiding immers gesteld tegenover de gederfde inkomens en de gemaakte studiekosten, die aan budgetrestricties onderhevig kunnen zijn.

Bij de school konden de volgende gegevens over de gezinssituatie van de leerlingen worden verkregen:

- de vader oefent een wetenschappelijke of beleidvoerende functie uit;

- de vader oefent een administratieve of commerciële functie uit;

- de vader oefent een dienstverlenende functie uit;

- de vader oefent een bouwberoep uit;

- de vader oefent een chauffeurs- of verwante functie uit;

- de vader oefent een ambachts-, industrie- of transportberoep uit;

- de vader oefent een ander beroep uit ("arbeider");

- het gezin ontvangt voor de desbetreffende leerling een tegemoetkoming in de studiekosten. 


\section{MODEL}

De eindexamenleerlingen moeten een keuze maken uit een eindig aantal alternatieven, derhalve wordt een model gespecificeerd dat behoort tot de modellen "with qualitative dependent variables" (Judge c.s., 1982). Kenmerkend voor deze qualitative response modellen is, dat de afhankelijke variabele niet continu is maar discreet en derhalve slechts een eindig aantal waarden kan aannemen (Amemiya, 1981).

De belangrijkste voorwaarden waaraan een qualitative response model moet voldoen zijn:

$P_{i j} \succeq 0$

$\sum_{j=1}^{J} P_{i j}=1$

waarbij $P_{i j}$ de kans is dat leerling i alternatief $\mathrm{j}$ kiest met een totaal van $\mathrm{J}$ alternatieven.

Het meest eenvoudige qualitative response model is het model met slechts twee keuzemogelijkheden $(\mathrm{J}=2)$; dit is het binomiale keuzemodel. Als de leerling uit meerdere mogelijkheden kan kiezen, dan is het multinomiale keuzemodel van toepassing. De schattingstechniek die in dit onderzoek zal worden gebruikt is de Maximum-Likelihood-methode.

Er zal eerst worden getracht te bepalen door welke kenmerken de kans wordt bepaald dat een leerling er voor kiest om na het eindexamen aan de lagere technische school full-time verder te gaan leren, full-time te gaan werken of part-time te gaan werken en leren. Daarna zal voor de leerlingen die na het eindexamen een vervolgopleiding willen gaan volgen, worden nagegaan welke kenmerken de kans bepalen dat een leerling kiest voor een bepaalde vervolgopleiding.

Twee bekende modellen die de kans verklaren dat een economische eenheid of individu een bepaalde keuze maakt, zijn het probit- en het logit-model. Deze twee modellen gaan uit van de latente variabele $y_{i}^{*}$, die wordt gedefinieerd door de volgende vergelijking:

$$
y_{i}^{*}=\beta^{\prime} x_{i}+e_{i}
$$

met: $x_{i}=$ vector van de kenmerken van leerling $\mathrm{i}$ en van de alternatieven zoals die door de leerling worden waargenomen;

$\beta=$ vector van onbekende coëfficiënten;

$e_{i}=$ storingsterm. 
In de praktijk is $y_{i}^{*}$ niet waar te nemen. Wat wel waargenomen kan worden is de dummy variabele $y_{i}$, die als volgt wordt gedefinieerd:

$y_{i}= \begin{cases}1 & \text { als } y_{i}^{*}>0 \\ 0 & \text { elders }\end{cases}$

De normale verdeling van het probit-model en de logistische verdeling van het logit-model lijken erg veel op elkaar, behalve bij de uiteinden, derhalve zullen de empirische resultaten van het probit- en het logit-model weinig van elkaar verschillen (Maddala, 1983). Omdat het toepassen van het logit-model eenvoudiger en sneller gaat, vooral in een situatie waarin een leerling uit meer dan twee alternatieven kan kiezen, wordt in deze studie alleen gebruik gemaakt van het logit-model.

Er is echter een voorwaarde voor het gebruiken van het logit-model. Deze voorwaarde is, dat de relatieve kansen dat een leerling kiest tussen de alternatieven $\mathrm{j}$ en $\mathrm{k}$ niet mogen worden beïnvloed door het voorkomen van nog andere alternatieven. In deze studie wordt verondersteld dat aan dit "axiom of independence from irrelevant alternatives" (Chow, 1983) wordt voldaan.

Het logit-model veronderstelt het volgende verband tussen $P_{i}$ en de exogenen $x_{i}$ :

$P_{i}=G\left(\beta^{\prime} x_{i}\right)=\frac{1}{1+e^{-\beta^{\prime} x_{i}}}=\frac{e^{\beta^{\prime} x_{i}}}{e^{\beta^{\prime} x_{i}}+1}$

waarbij $G\left(\beta^{\prime} x_{i}\right)$ gelijk is aan de verdelingsfunctie van de logistische verdeling.

Om de kans te verklaren dat een leerling met een aantal bekende kenmerken kiest voor wel of niet full-time verder leren, wordt het volgende gedefinieerd:

$x_{i}=$ vector van de kenmerken van de leerling die van belang kunnen zijn voor de alternatieven zoals die door de leerling worden waargenomen;

$\beta=$ vector van onbekende coëfficiënten.

Vergelijking (3) geeft weer dat de te bepalen kans een functie is van $\beta^{\prime} x_{i}$, waarbij voldaan is aan de eis dat de kans tussen 0 en 1 moet liggen. 
$-10-$

Bij het schatten zullen twee varianten van het logit-model aan de orde komen, namelijk het binomiale en het multinomiale keuzemodel. Deze varianten worden uitvoeriger besproken in respectievelijk bijlage 1 en 2. 


\section{SCHATTINGSRESULTATEN}

Met betrekking tot de keuze tussen voltijd verder leren, voltijd gaan werken en werken in combinatie met leren is gebruik gemaakt van een sequentieel logit-model (Weiler, 1986). Daarin wordt verondersteld dat de keuzes die een leerling maakt elkaar opvolgen. In het geval van de hier te onderzoeken probleemstelling betekent dit dat de keuze die de leerling maakt in twee stappen verloopt. Als eerste zal de leerling afwegen of hij wel of niet na zijn eindexamen aan de lagere technische school voor hele dagen naar school wil gaan. Indien dit laatste niet het geval is, moet de leerling afwegen of hij helemaal geen vervolgopleiding meer wil gaan volgen of dat hij tenminste nog één of twee dagen in de week naar school wil gaan. Deze keuzes zijn schematisch weergegeven in figuur 1 (zie hoofdstuk 3 ).

Om het volledige model te schatten zal eerst het binomiale model worden gebruikt om de parameters te schatten voor de keuze tussen wel of niet full-time leren. Vervolgens zal op de deelverzameling van leerlingen die niet full-time gaan verder leren, het binomiale model worden toegepast om de parameters te schatten voor de alternatieven: full-time werken of werken gecombineerd met leren. Het multinomiale logit-model kan dus worden teruggebracht tot een opeenvolgende schatting van twee dichotome modellen, waarbij het tweede binomiale model op een kleiner aantal leerlingen betrekking heeft. Voorwaarde voor deze wijze van schatten is dat de opeenvolgende fasen van het sequentiële model niet één of meer dezelfde parameters bevatten.

Om te voorkomen dat de verklarende variabelen volledig met elkaar samenhangen, worden voor een discrete variabele met $n$ mogelijkheden $n-1$ dummy's opgenomen. Dit houdt in dat slechts het verschil in effect van de dummy-variabele ten opzichte van een referentievariabele wordt gemeten. Daarbij is het referentiekader met betrekking tot de studieniveaus vastgesteld op Bniveau. Als referentievariabele voor het beroep van de vader is de categorie "ambachts-, industrie- en transportberoepen" gekozen. Dit betekent dat alle variabelen dichotoom zijn (1: kenmerk aanwezig, 0 : kenmerk niet aanwezig), met uitzondering van 10 en vakcijfers die continu zijn.

Voordat de schattingsresultaten van het sequentiële logit-model worden besproken, moet worden opgemerkt dat de waarden van de parameterschattingen niet direct interpreteerbaar zijn. De mate van vergroting of verkleining van de kans dat een leerling een bepaalde keuze maakt is namelijk afhankelijk van de kansen in de "uitgangssituatie". Het teken van de parameters is wel interpretabel. 
Tabel 1. Schattingsresultaten binomiale logit-model van de keuze voor voltijd leren of werken en van de keuze voor voltijd werken of werken gecombineerd met leren.

\begin{tabular}{lcccc}
\hline & $\begin{array}{c}\text { voltijd onderwijs } \begin{array}{c}\text { t.o.v. werken } \\
\text { (evt. in combinatie met leren) } \\
\text { Variabele }\end{array} \\
\text { par.waarde }\end{array}$ & $\begin{array}{l}\text { t-ratio } \\
\text { voltijd werken t.o.v. } \\
\text { werken en leren } \\
\text { par.waarde }\end{array}$ & t-ratio \\
\hline Constante & 1.46 & 0.52 & 2.58 & 0.24 \\
& & & & \\
Arbeidsmarktmotieven & & & & \\
$\begin{array}{l}\text { Beroepswens } \\
\text { Inkomensvooruitzichten }\end{array}$ & -1.13 & $-2.34^{* *}$ & 2.13 & $2.30^{* *}$ \\
& 2.95 & $4.87^{* *}$ & 4.67 & 0.49
\end{tabular}

Inschatten van de kans op succes in een vervolgopleiding

Studieniveau van de leerling ten opzichte van het referentieniveau B:

$\begin{array}{lrrrr}\text { A/B studieniveau } & -0.84 & -1.16 & -0.12 & -0.11 \\ \text { B/C/D studieniveau } & 0.65 & 1.13 & 0.22 & 0.17 \\ & & & & \\ \text { IQ-score } & -0.01 & -0.30 & 0.03 & 0.84 \\ \text { Cijfer alle vakken } & 0.09 & 0.44 & 0.17 & 0.48\end{array}$

Budgetbeperking en het gebrek aan informatie

Beroep van de vader ten opzichte van de referentiecategorie "ambachts-, industrie- en transportberoepen":

$\begin{array}{lll}\text { Wetenschappelijke/beleidvoerende functie } & 0.61 & 0.61 \\ \text { Administratieve/commerciële functie } & 1.49 & 2.03^{* *} \\ \text { Dienstverlenende functie } & 0.65 & 0.84 \\ \text { Bouwvakarbeider } & 1.83 & 1.44 \\ \text { Chauffeur } & -0.09 & -0.12 \\ \text { Arbeider } & -0.17 & -0.22\end{array}$

Aantal jaren opleiding
-
$\begin{array}{ll}- & 0.03\end{array}$
0.19

Log-likelihood $\quad-59.65$

$\mathrm{n}=145$

$-18.23$

51

$\begin{array}{ll}* * & \text { significant op } 5 \% \text {-niveau } \\ * & \text { significant op } 10 \% \text {-niveau }\end{array}$

Zoals hierboven is aangegeven, betreft het eerste te schatten model de tweevoudige keuze tussen wel of niet voltijd doorleren. De resultaten zijn weergegeven in tabel 1 . Voor de interpretatie van de parameterschattingen is van belang dat deze schattingen gelden voor de situatie voltijd doorleren, ten opzichte van de situatie werken al dan niet gecombineerd met 
leren. Dit betekent dat als een variabele een positief effect heeft op de keuze om na het eindexamen voltijd verder te leren, dezelfde variabele automatisch een negatief effect heeft op de keuze om te gaan werken (eventueel in combinatie met leren).

Het blijkt dat het hebben van een specifieke beroepswens een significant negatieve invloed heeft op de voorkeur voor voltijd doorleren boven werken, al dan niet gecombineerd met leren. Het belang dat wordt gehecht aan goede inkomensvooruitzichten heeft daarentegen een significant positieve invloed op deze voorkeur. Verder blijkt dat de inschatting van de kans op succes geen significante rol speelt bij de keuze om al dan niet voltijd onderwijs te gaan volgen. Tenslotte blijken leerlingen uit gezinnen met een vader die een administratief of commercieel beroep heeft significant vaker te kiezen voor voltijd doorleren.

Het tweede model dat wordt geschat betreft de keuze, van de leerlingen die niet voltijd willen doorleren, tussen voltijd werken of het combineren van werken met leren. Bij deze schatting vormen de leerlingen die kiezen voor werken gecombineerd met leren de referentiegroep. Dit betekent dat als een variabele een positief effect heeft op de keuze om na het eindexamen voltijd te gaan werken, deze automatisch een negatief effect heeft op de keuze om te gaan werken in combinatie met leren.

Door gebrek aan waarnemingen is de variabele beroep van de vader vervangen door het (geschatte) aantal jaren opleiding dat de vader heeft gevolgd. De schattingsresultaten zijn in tabel 1 weergegeven. Het hebben van een specifieke beroepswens blijkt een significante stimulans te vormen om na de LTS direct een volledige baan te zoeken. De overige variabelen zijn niet significant.

Het derde model dat wordt geschat betreft de keuze van de leerlingen die voltijd vervolgonderwijs willen volgen voor een bepaald type vervolgopleiding. Hiervoor wordt gebruik gemaakt van het multinomiale logit-model. De alternatieven zijn: naar de MTS gaan, een voltijd KMBO-opleiding volgen, terugkeren naar de LTS voor een vijfde leerjaar of een andere voltijd opleiding volgen. Het willen terugkeren naar de LTS geldt als referentiegroep. Dit betekent dat in dit model alleen het verschil kan worden gemeten tussen enerzijds het terugkeren naar de LTS en anderzijds het verder leren aan de MTS, voltijd-KMBO of een andere voltijd opleiding.

De arbeidsmarktmotieven (goede inkomensvooruitzichten en specifieke beroepswens) spelen door hun zeer algemene formulering geen rol bij deze specifieke richtingkeuze. Daarom worden alleen de schattingen gepresenteerd waarin zij niet zijn meegenomen. De schattingsresultaten zijn in tabel 2 weergegeven. 
Tabel 2. Schattingsresultaten multinomiale logit-model van de keuze voor een bepaalde vervolgopleiding ten opzichte van terugkeren naar de LTS.

\begin{tabular}{lcccccc}
\hline & \multicolumn{2}{c}{$M T S$} & \multicolumn{2}{c}{ voltijd-KMBO } & \multicolumn{2}{c}{ Overig } \\
Variabele & par.waarde & t-ratio & par.waarde & t-ratio & par.waarde & t-ratio \\
\hline & & & & & & \\
Constante & -5.69 & -0.75 & -2.15 & -0.51 & -4.29 & -0.51
\end{tabular}

Inschatten van de kans op succes in een vervolgopleiding

Studieniveau van de leerling ten opzichte van het referentieniveau B of lager:

\begin{tabular}{|c|c|c|c|c|c|c|}
\hline $\mathrm{B} / \mathrm{C} / \mathrm{D}$ studieniveau & 8.24 & $3.46^{* *}$ & -0.17 & -0.09 & 2.34 & 1.08 \\
\hline Profielverbeteraar & 0.74 & 0.40 & 1.60 & 1.65 & -0.22 & -0.11 \\
\hline Doubleur & -0.83 & -0.52 & -0.24 & -0.16 & 0.82 & 0.61 \\
\hline IQ-score & 0.06 & 0.97 & -0.01 & -0.20 & -0.06 & -0.94 \\
\hline Cijfer talen & -0.63 & -0.92 & -0.16 & -0.39 & 0.98 & 1.01 \\
\hline Cijfer wis- en natuurkunde & 0.66 & $2.32^{* *}$ & 0.59 & $1.86^{*}$ & -0.01 & -0.04 \\
\hline Cijfer praktijkvakken & -0.14 & -0.24 & -0.61 & -1.38 & -0.11 & -0.16 \\
\hline
\end{tabular}

Budgetbeperking en het gebrek aan informatie

\begin{tabular}{|c|c|c|c|c|c|c|}
\hline $\begin{array}{l}\text { Aantal jaren opleiding } \\
\text { vader }\end{array}$ & -0.46 & -1.57 & 0.26 & 1.05 & 0.05 & 0.13 \\
\hline $\begin{array}{l}\text { Tegemoetkoming in } \\
\text { studiekosten }\end{array}$ & 0.47 & 0.33 & 0.52 & 0.70 & -0.77 & -0.57 \\
\hline
\end{tabular}

Log-likelihood van het multinomiale logit-model $=-55.81$

$\mathrm{n}=94$

* $\quad$ significant op $5 \%$-niveau

* significant op $10 \%$-niveau

In het multinomiale logit-model is alleen de variabele voor een B-studieniveau of hoger meegenomen. De reden hiervoor is dat leerlingen ten minste $B / C$-niveau moeten hebben om tot de MTS te worden toegelaten. Het is dan ook overeenkomstig de verwachting dat ten aanzien van de keuze voor de MTS de parameter voor B/C/D-studieniveau significant groter is dan 0 .

Toegevoegd zijn variabelen die betrekking hebben op de studieresultaten voor bepaalde vakken (talen, wis- en natuurkunde en praktijk), omdat deze voor de richtingkeuze relevant lijken; zo stelt in het bijzonder de MTS zwaardere eisen. Uit tabel 2 blijkt de belangstelling voor de MTS inderdaad significant sterker te zijn naarmate men hogere cijfers heeft behaald voor de (theoretische) wis- en natuurkundevakken. Hogere cijfers voor wis- en natuurkunde zijn ook van 
$-15-$

belang voor de keuze voor voltijd-KMBO, hoewel het significantieniveau lager ligt.

Tenslotte laten de schattingsresultaten zien dat de parameters voor het aantal jaren opleiding van de vader en voor tegemoetkoming in de studiekosten niet significant van 0 verschillen. De herkomst heeft dus weinig of geen invloed op de keuze van vervolgopleiding als de leerling al heeft beslist dat hij full-time verder wil gaan leren. 


\section{CONCLUSIES}

Uitgaande van een drietal economische theorieën is op verkennende wijze onderzocht welke factoren een rol spelen bij de beslissingen van eindexamenleerlingen over de te volgen loopbaan direct na afsluiting van de LTS. De globale wijze waarop deze theorieën in te onderzoeken variabelen moesten worden vertaald, maakt het onmogelijk op basis van de gevonden resultaten een voorkeur uit te spreken voor de ene theorie boven de andere. Daarvoor had het onderzoek meer licht moeten werpen op de vraag of het onderwijs het produktief vermogen van leerlingen vergroot (human capital) dan wel slechts informatie geeft over de reeds aanwezige kwaliteiten (screening en labor queue theorie), alsmede op de betekenis van on-the-job training voor het verwerven van de benodigde kennis en vaardigheden (labor queue). De schattingsresultaten laten echter wel zien dat voor de onderzochte groep leerlingen het algemene uitgangspunt van deze theorieën opgaat. De schoolverlaters investeren in vervolgonderwijs, omdat het inkomen dat zij daarna verwachten hoger is dan het inkomen dat zij denken te verdienen als verder geen onderwijs meer wordt gevolgd.

Verder laten de schattingsresultaten zien dat het hebben van een specifieke beroepswens een reden kan vormen voor het niet continueren van de schoolloopbaan en dat leerlingen die nog geen duidelijke beroepswens hebben hun intrede op de arbeidsmarkt uitstellen door het deelnemen aan een vervolgopleiding. Het hebben van slechts vage beroepswensen geldt voor zowel leerlingen die willen doorstromen naar het leerlingwezen, dus leren en werken willen combineren, als leerlingen die voltijd vervolgonderwijs willen volgen.

De ingeschatte kansen op succes in een vervolgopleiding, die onder meer een rol spelen in de screening theorie, lijken alleen van belang te zijn voor de keuze van het type vervolgopleiding. Zo bleek het behalen van goede studieresultaten de keuze voor de MTS en -in mindere matehet voltijd KMBO te bevorderen. Met betrekking tot de keuze voor de MTS heeft het B/C/Dniveau een positief significante invloed.

Met betrekking tot het ontvangen van gebrekkige of selectieve informatie over de latere loopbaanmogelijkheden of mogelijke budgettaire beperkingen bleek uit de schattingsresultaten dat leerlingen uit gezinnen met een vader die een administratief of commercieel beroep heeft significant vaker te kiezen voor voltijd doorleren. Als de leerling eenmaal heeft beslist om verder te leren, heeft de herkomst geen of weinig invloed op de keuze van het type vervolgopleiding. 


\section{LITERATUUR}

Amemiya, T. (1981), Qualitative response models: a survey, Journal of Economic Literature, volume XIX, blz. 1483-1536.

Chow, G.C, (1983), Econometrics, McGraw/Hill, New York.

Judge, G.G., R.C. Hill, W. Griffiths, H. Lütkepohl, T.C. Lee (1982), Introduction to the theory and practice of econometrics, John Wiley \& Sons, New York.

Maddala, G.S. (1983), Limited-dependent and qualitative variables in econometrics, Cambridge University Press, Cambridge.

Schultz, T.W. (1961), Investment in human capital, American Economic Review, volume 51, blz. 1-17.

Spence, O.F. (1973), Job market signaling, Quarterly Journal of Economics, blz. 355-374.

Stiglitz, J.E. (1975), The theory of screening, education and distribution of income, American Economic Review, volume 66, blz. 283-300.

Stijnen, F.H.H.C. en M.H. Wieling (1988), Arbeidsmarktverwachtingen en arbeidsmarktpositie van LTS-ers: verslag van een enquête onder eindexamenleerlingen en schoolverlaters van de Technische School Maastricht, Rijksuniversiteit Limburg, Researchcentrum voor Onderwijs en Arbeidsmarkt, Maastricht.

Thurow, L.C. (1979), A job competition model, in: Piore (ed.), Unemployment and inflation institutionalist and structuralist views, White Plains, New York, blz. 17-32.

Weiler, W.C. (1986), A sequential logit model of the access effects of higher education institutions, Economics of Education Review, volume 5, no. 1, blz. 49-55.

Wieling, M.H. (1990), De keuze van LTS-leerlingen voor verder leren of werken, Afstudeerscriptie, Faculteit der Economische Wetenschappen van de Rijksuniversiteit Limburg, Maastricht. 


\section{BIJLAGE 1: HET BINOMIALE LOGIT-MODEL}

In het geval dat een leerling een keuze moet maken tussen twee alternatieven kan men gebruik maken van het binomiale logit-model. Er kan zo bijvoorbeeld worden onderzocht of de leerling kiest voor al of niet full-time verder leren na zijn eindexamen.

Het maken van deze binaire keuze kan door middel van een dummy worden weergegeven, namelijk:

$y_{i}= \begin{cases}1 & \text { als leerling i full-time verder wil gaan leren } \\ 0 & \text { als leerling i niet full-time verder wil gaan leren }\end{cases}$

De kans dat leerling i, die een aantal bekende karakteristieken heeft, na zijn eindexamen kiest voor full-time verder leren, is (zie ook vergelijking (3) in hoofdstuk 4):

$$
\operatorname{Prob}\left(y_{i}=1\right)=P_{i}=\frac{1}{1+e^{-\beta^{\prime} x_{i}}}=\frac{e^{\beta^{\prime} x_{i}}}{e^{\beta^{\prime} x_{i}}+1}
$$

en de kans dat leerling i, die een aantal bekende karakteristieken heeft, na zijn eindexamen kiest voor werken eventueel in combinatie met leren, is:

$\operatorname{Prob}\left(y_{i}=0\right)=1-P_{i}=\frac{1}{1+e^{\beta^{\prime} x_{i}}}$

De likelihood-functie kan nu als volgt worden geformuleerd:

$L=\prod_{i=1}^{n} P_{i}^{y_{i}}\left(1-P_{i}\right)^{\left(1-y_{j}\right)}$

De log-likelihood-functie wordt dan:

$$
\log L=\sum_{i=1}^{n}\left[y_{i} \log P_{i}+\left(1-y_{i}\right) \log \left(1-P_{i}\right)\right]
$$




$$
\begin{aligned}
& =\sum_{i=1}^{n}\left\{y_{i}\left[\log P_{i}-\log \left(1-P_{i}\right)\right]+\log \left(1-P_{i}\right)\right\} \\
& =\sum_{i=1}^{n} y_{i} \beta^{\prime} x_{i}-\sum_{i=1}^{n} \log \left(1+e^{\beta^{\prime} x_{i}}\right)
\end{aligned}
$$

De log-likelihood-functie wordt vervolgens naar $\beta$ gedifferentieerd om de Maximum-Likelihoodschatter voor $\beta$ te verkrijgen. 


\section{BIJLAGE 2: HET MULTINOMIALE LOGIT-MODEL}

In het geval dat een leerling een keuze moet maken tussen meer dan twee alternatieven kan men gebruik maken van het multinomiale logit-model. Dit is het geval, wanneer wordt geprobeerd de kans te verklaren dat een leerling die na het eindexamen full-time verder wil gaan leren, kiest voor een bepaalde vervolgopleiding.

Ook in dit geval wordt een dummy geïntroduceerd om de likelihood-functie te kunnen formuleren, namelijk:

$y_{i j}= \begin{cases}1 & \text { als leerling } \mathrm{i} \text { opleiding } \mathrm{j} \text { kiest } \\ 0 & \text { elders }\end{cases}$

De kans dat leerling $i$, die na zijn eindexamen kiest voor full-time verder leren, vervolgopleiding $j$ kiest is:

$$
P_{i j}=\frac{e^{\beta_{j}^{\prime} x_{i j}}}{\sum_{k=1}^{J} e^{\beta_{k}^{\prime} x_{i k}}}
$$

In deze formule geeft de kolomvector $x_{i j}$ de kenmerken behorend bij leerling $\mathrm{i}$ en opleiding $\mathrm{j}$ aan, waarbij er in totaal $\mathrm{n}$ leerlingen en $\mathrm{J}$ alternatieve vervolgopleidingen zijn.

Anders geformuleerd wordt (2):

$$
P_{i j}=\frac{e^{\beta_{j}^{\prime} x_{i j}}}{1+\sum_{k=1}^{J-1} e^{\beta_{k}^{\prime} x_{i t}}} \quad(j=1, \ldots, J-1)
$$

en

$$
P_{i J}=\frac{1}{1+\sum_{k=1}^{J-1} e^{\beta_{k}^{\prime} x_{i k}}}
$$


Per definitie geldt dat de hierboven genoemde kansen optellen tot één, dus:

$\sum_{j=1}^{J} P_{i j}=1$

waarbij $\boldsymbol{P}_{i j}$ de kans is dat leerling $\mathrm{i}$ vervolgopleiding j kiest met een totaal van $\mathrm{n}$ leerlingen en $\mathrm{J}$ alternatieve opleidingen.

De likelihood-functie kan nu als volgt worden geformuleerd:

$L=\prod_{j=1}^{n} P_{i 1}^{y_{u I}} P_{i 2}^{y_{12}} \ldots P_{i J}^{y_{W}}$

De log-likelihood-functie wordt dan:

$$
\begin{aligned}
\log L & =\sum_{i=1}^{n} \sum_{j=1}^{J} y_{i j} \log P_{i j} \\
& =\sum_{i=1}^{n} \sum_{j=1}^{J} y_{i j} \log \left(\frac{e^{\beta_{k}^{\prime} x_{i j}}}{\sum_{k=1}^{J} e^{\beta_{k}^{\prime} x_{k i}}}\right) \\
& =\sum_{i=1}^{n} \sum_{j=1}^{J} y_{i j} \beta_{j}^{\prime} x_{i j}-\sum_{i=1}^{n} \sum_{j=1}^{J} y_{i j} \log \left(\sum_{k=1}^{J} e^{\beta_{k}^{\prime} x_{i k}}\right)
\end{aligned}
$$

Ook nu wordt de log-likelihood-functie naar $\beta$ gedifferentieerd om de Maximum-Likelihoodschatter voor $\beta$ te verkrijgen. 